\title{
SHEEP PRODUCTIVITY IN AN ASTREBLA GRASSLAND OF SOUTH-WEST QUEENSLAND
}

\author{
D.M. Orr 1,2, C.J. Evenson'1, D.J. Jordan ${ }^{1,3}$, P.S. Bowly1,3, K.J. Lehane ${ }^{1,4}$ and D.C. Cowan ${ }^{1,5}$
}

${ }^{1}$ Department of Primary Industries, Charleville Pastoral Laboratory, P.O. Box 282, Charleville 4470.

Present address:

2. Department of Primary Industries, Brian Pastures Research Station, Gayndah 4625.

3 Department of Primary Industries, P.O. Box 308, Roma 4455.

${ }^{4}$ Department of Primary Industries, P.O. Box 102, Toowoomba 4350.

5 Department of Primary Industries, Arid Zone Research Institute, Longreach 4730.

\begin{abstract}
A grazing study conducted between 1979 and 1983 assessed the seasonal trends of ewe productivity in Astrebla grassland in southwestern Queensland. This study was designed originally to compare productivity on two pastures with different compositions, however, these differences in pastures composition were not achieved.
\end{abstract}

Large differences in liveweight, wool growth and reproductive performance occurred between years in response to differences in pasture growth resulting from large variation in the seasonal incidence of rainfall. Rainfall effective for plant growth, both forbs and grasses, resulted in a high quality diet which resulted, in tum, in increased sheep productivity. Reproductive performance was particularly sensitive to the quality of the ewes diet around the time of lambing through the effect of diet quality on lamb survival and growth rate.

It is suggested that the effect of rainfall on reproductive performance is of greater importance than the yield of forbs present in the pasture.

\section{Introduction}

Lambing performance is an important factor in the economic success of primary producers in Astrebla (Mitchell grass) grasslands, as high lambing performance contributes substantially to income through the sale of surplus sheep (Holmes 1983).

Above average summer rainfall in Astrebla grassland increases the yield of perennial grasses and results in reduced pasture utilization where normal stocking rates are maintained. If heavy rainfall occurs in the following summer, there is a further shift towards perennial grass dominance at the expense of the annual grass and fort component (Orr 1980, 1981). Sheep grazing Astrebla grassland preferentially graze forb species when they are available in the pasture (Lorimer 1978, McMeniman et al. 1986a). Sheep liveweight is correlated positively with the forb content and negatively with the Astrebla spp. content of the diet (Lorimer 1978).

Poor sheep performance, particularly lamb marking percentages, occurred in Astrebla grasslands during the period 1974 and 1976 and was associated with a series of years with above average summer rainfall. A similar decline in sheep performance occurred in 1951 and 1953 during a period of years with above average summer rainfall. Thus the poor performance which occurs during a series of summers with heavy rainfall may be the result of a shift towards perennial grass dominance in the pasture.
Accordingly, we treated one paddock to see if we could 'open up' the pasture to increase the forb content and measured the productivity, particularly reproduction, of sheep grazing these pastures. This paper presents pasture and sheep data collected over a five year period and compares sheep productivity between years in relation to trends in seasonal rainfall.

\section{Methods}

\section{Pasture management}

The study was established in Astrebla grassland at "Biddenham" Augathella on an area within the Allaru land system (Turner 1978) which is representative of a major portion of Astrebla grasslands in Queensland.

An area of 120 ha was selected in November 1978 and fenced into two paddocks each of 60 ha. One of these paddocks (the modified) was burnt in December 1978 to remove the large body of dry perennial grass and further pasture modification by grazing was attempted during the $1980 / 81,1981 / 82$ and $1982 / 83$ summers. During these periods ewes and lambs from both the control and modified paddocks grazed the modified paddock from the last sheep measurements in December each year until sufficient rainfall occurred to promote plant growth, after which they were removed (see Sheep Management).

The second paddock was maintained as a control grazing paddock. There were no replications of the treatments. 


\section{Pasture measurement}

Dry matter yield and botanical composition of each paddock were determined two and three times annually using the "rank set" sampling procedure (Halls and Dell 1966), in conjunction with the sampling for diet quality (see Diet Quality). Each paddock was divided into 15 sections of equal size, which were used to randomly distribute the 50 sets of quadrats throughout the paddock. At each placement of the quadrat sets, the occurrence of all forb and grass species in the selected quadrat was recorded. The total standing dry matter of each species was then harvested separately for subsequent dry and weighing. No harvests were made in July 1980 or during 1983. Statistical analysis of yields at each sampling was conducted using the method outlined in Halls and Dell (1966).

\section{Sheep management and measurements}

Grazing started each year when sufficient rainfall was received between January and March to promote plant growth. A group of 100 ewes was stratified on body weight and divided into two groups which were placed in the two experimental paddocks. This gave a stocking rate of 1 sheep/1.2 ha which is "district average" for the general study. Three different groups of ewes, each aged three years at the start of grazing were used during this study: one in 1979, a second group between 1980 and 1982 and a third group during 1983.

Ewes were weighed and sampled for wool growth rate at six to eight weekly intervals. Ten ewes in each paddock were selected on stratified body weight for the measurement of wool growth rate using the clip patch technique. All sheep were shorn in December. Analysis of variance was conducted on liveweight change and also on wool growth rates (using the previous wool growth rate as a covariate) with individual data from within a paddock as the estimate of error. (Such analysis can only distinguish between the two groups of animals and not necessarily between treatments).

\section{Reproductive performance}

The reproductive performance of the ewes was followed from joining through to lamb marking. Two rams with
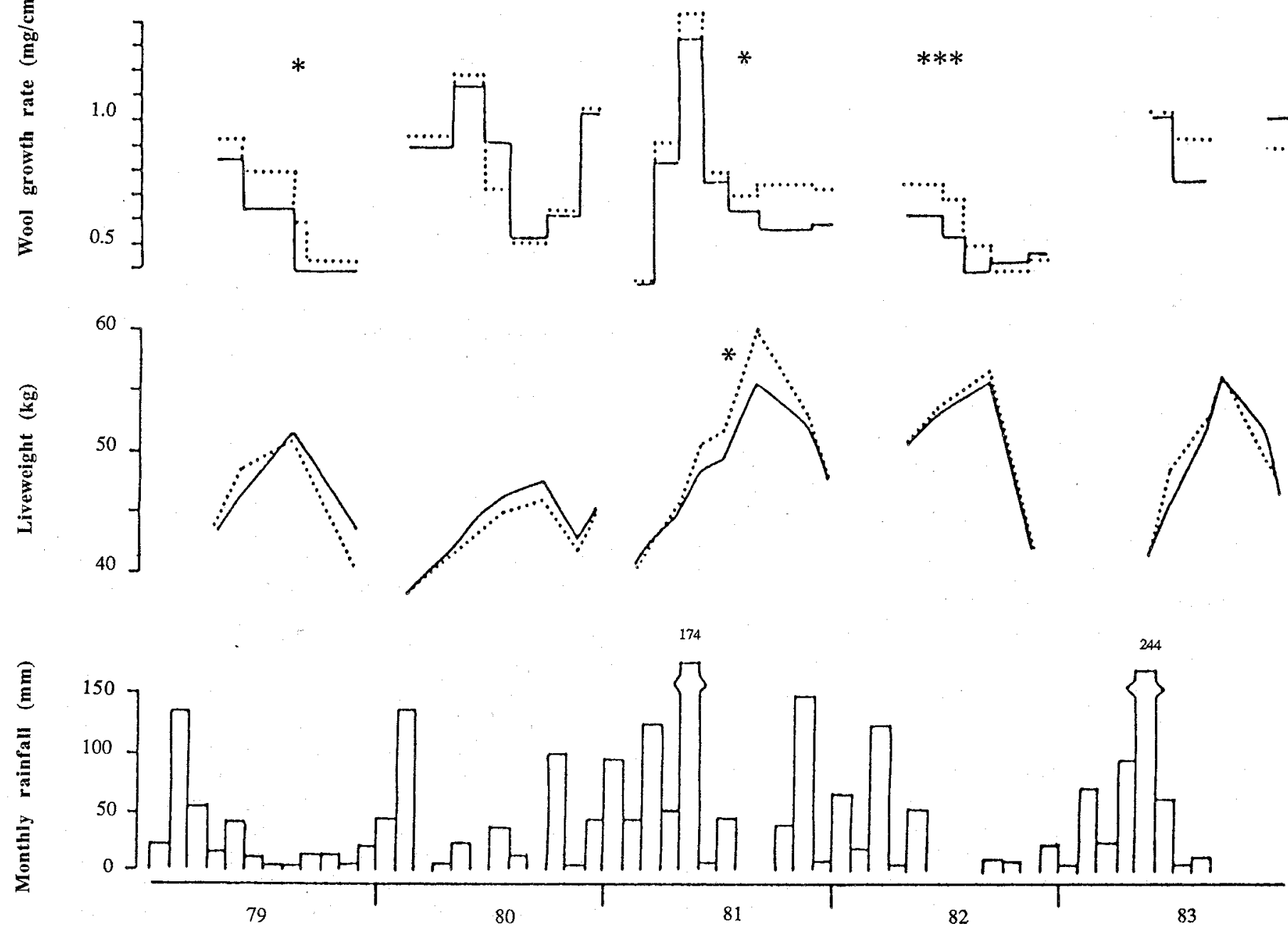

Figure 1. Monthly rainfall, ewe liveweight change and wool growth rates for ewes grazing the control $(\rightarrow)$ and modified (...) paddocks between 1979 and 1983 in Astrebla grasslands. [Significant differences $(\mathrm{P}<0.05)$ are indicated] 
palpably normal scrotal contents were fitted with Siresine harnesses and crayons (Radford et al. 1960) and introduced to each paddock in mid-April each year for a six week joining. Mating records were made fortnightly. The pregnancy status of ewes was determined by udder palpation and ballotment (Pratt and Hopkins 1975) prior to the start of lambing in September.

The number and liveweight of lambs, and ewe liveweight, were recorded simultaneously with wool growth sampling in November, two weeks after the completion of lambing. Lamb liveweights were recorded again four weeks later and growth rates were calculated by difference for the years 1980 to 1983 . In November 1980, 1981, 1982 and 1983 ewe milk yield was determined by the method of McCance (1959) from ten lactating ewes in each paddock.

\section{Diet quality}

Five wethers each fitted with an oesophageal fistula were introduced to the trial paddocks usually two or three times per year (autumn, winter and post lambing) to determine diet quality using procedures described by McMeniman et al. (1986a). For each sampling occasion, fistula samples were collected in each paddock on four consecutive mornings following a period of one week during which the fistulated wethers were allowed to become accustomed to the paddock. Extrusa samples from each sheep were bulked separately and sub-samples were analysed for dietary nitrogen, sulphur, copper and zinc. In vitro digestible organic matter was determined using the two stage method of Tilley and Terry (1963).

No corrections were made for the effects of salivary contamination because McMeniman et al. (1986a) found that there was little effect with these elements. Botanical composition of the diet in each paddock was determined from a single bulked extrusa sample from all sheep using the microhistological technique of Sparks and Malechek (1968).

\section{Results and discussions}

\section{Rainfall}

A feature of this study was the occurrence of above average rainfall in October 1980, in May and July 1981 and in April, May and June 1983 (Fig. 1). All summers except 1982/83 received average to above average rainfall while in two years, 1979 and 1982, a wet summer was followed by a dry winter/spring.

\section{Pasture composition}

The pasture modification procedures failed to increase either the yield or frequency of forbs in the modified paddock (Tables 1 and 2). However, the yield of forbs in April 1979 was higher in the modified than in the control paddock and was associated with a higher yield and frequency of Calotis scabiosifolia ${ }^{1}$. This change

\footnotetext{
1 Species nomenclature follows Hartley (1979)
}

occurred after burning in December 1978 when the pasture was ungrazed from then until April 1979. A large variety of grass and forb species was present during the course of the study (Table 2).

Total yields were decreased by the modification treatment, except in 1981, due mainly to reduced yields and frequencies of Dichanthium sericeum, Panicum spp. and Digitaria ammophila. The yield of Astrebla spp. was also reduced in the modified paddock in 1979 and 1980, however, there were no differences in 1981 or 1982. Variation in pasture composition between years was more than that between the paddocks within years.

\section{Sheep liveweight}

Ewes generally gained weight until lambing, lost weight during lambing and then continued to lose weight until the end of the trial grazing period in December. Annual trends in liveweight change were similar for both paddocks (Fig. 1). In 1980 aboveaverage October rain was associated with an increase in liveweight in the period following lambing which was probably due to the availability of a high quality diet (Table 6). High diet quality at this time was probably due to an increase in the quality of the grass selected by sheep, as well as the quality of the forbs, because forb content of the diets varied from $58 \%$ in the control to only $14 \%$ in the modified paddock (Table 5). Ewe liveweight gain decreased following about $170 \mathrm{~mm}$ of rain in May 1981 (Fig. 1), although the diet of both groups contained over $50 \%$ forbs (Table 5) and was of good quality at this time (Table 6). This drop in rate of weight gain may have been due to decreased forage intake during the prolonged periods of heavy rain.

\section{Wool growth}

Wool growth rates were generally highest during autumn each year, fell during winter and spring and were similar in both paddocks (Fig. 1). They recovered rapidly in November to December 1980 but failed to increase during the very wet winter of 1981 despite high diet quality (Table 6). Wool growth rates in the modified paddock for the first three wool growth periods in 1982 were consistently higher than for the control paddock and resulted in a higher $(\mathrm{P}<0.05)$ greasy fleece weight at shearing in December 1982. Forb content was higher in the diet selected from the modified paddock (Table 5) in July 1982 and diet quality was marginally higher (Table 6).

\section{Reproductive performance}

Little variation occurred between years in the percertage of ewes joined and ewes pregnant (Table 3). In contrast, the percentage of lambs marked varied from 22 to $128 \%$ and lamb liveweight at marking from 7.0 to $15.2 \mathrm{~kg}$. Reduced lamb marking percentages in 1979 and 1982 were associated with low diet quality at the time of lambing (Table 6) and ewes were diagnosed as suffering pregnancy toxaemia. (Ewe losses were 26 and $19 \%$ in 
D.M. Orr et al.

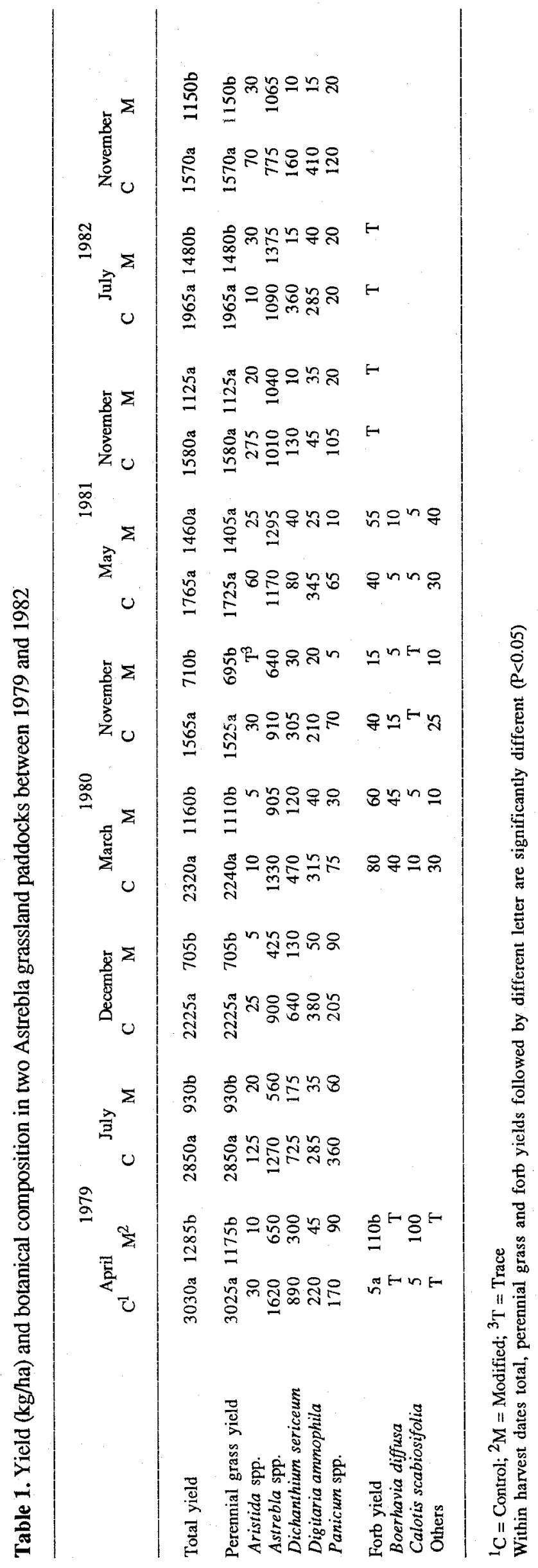




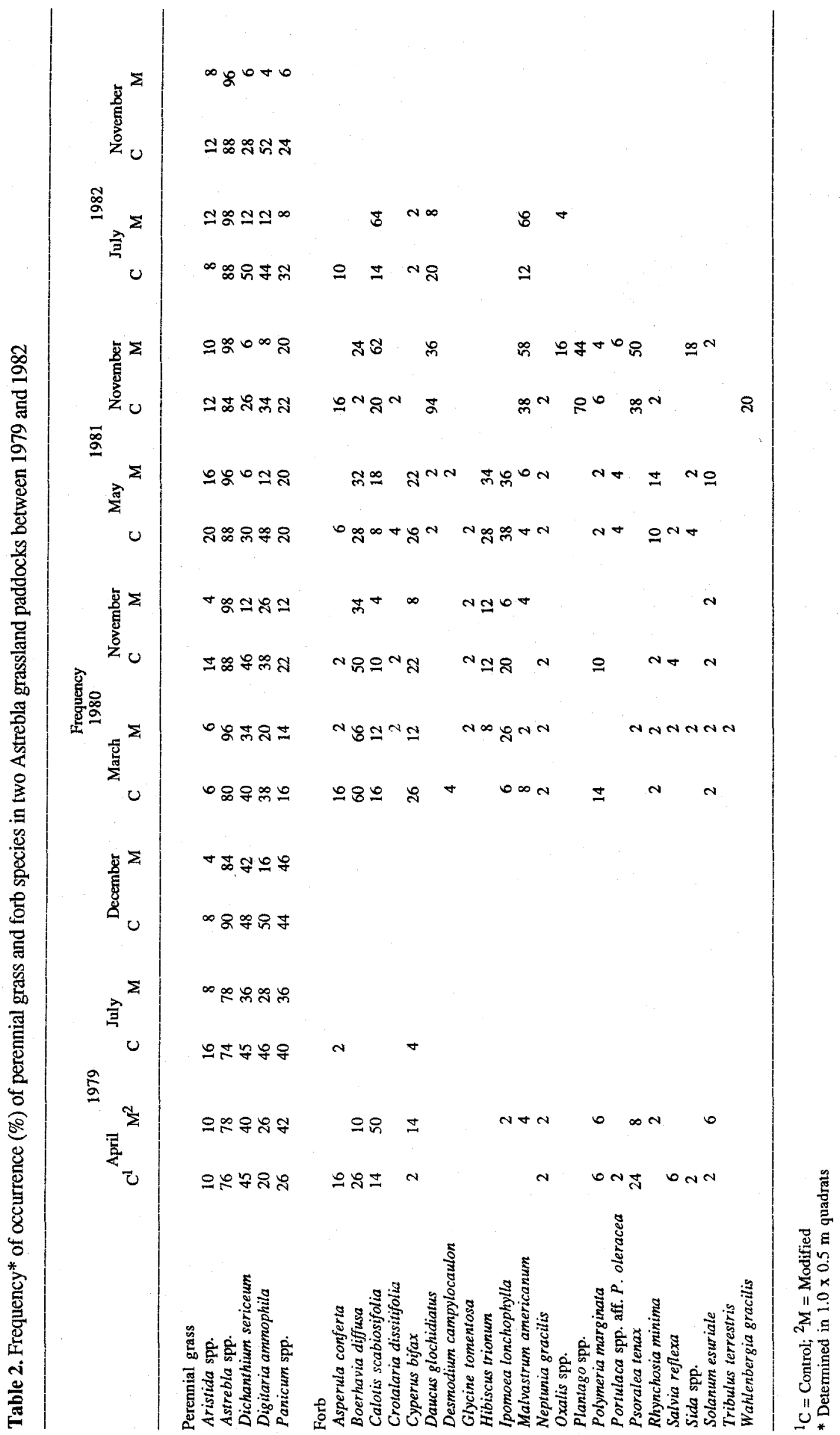


1979 and 1982 respectively compared with less than $6 \%$ in other years). Dead lambs were observed during lambing in both 1979 and 1982 . Feral pigs are known to have consumed lambs in the modified paddock during lambing in 1982 and may also have affected results from the adjacent control paddock.

Higher lamb marking percentages and lamb liveweights in 1980, 1981 and 1983 were associated with improved diet quality around the period of lambing (Table 6). Differences in reproductive performance between years were consistently larger than between paddocks.

\section{Ewe milk yield and lamb growth rate}

Ewe milk yields and lamb growth rates showed large annual variation with a range in ewe milk yields from 280 to $1,280 \mathrm{~mL} / \mathrm{hd} / \mathrm{d}$ and lamb growth rates from 22 to $209 \mathrm{~g} / \mathrm{hd} / \mathrm{d}$ (Table 4 ). High ewe milk yields and lamb growth rates were associated with improved diet quality, particularly nitrogen content, in the period around lambing.

\section{Diet composition}

A comparison of species available in the pasture (Tables 1 and 2) and in the diet (Table 5) indicated that sheep preferentially grazed forb species such as Boerhavia diffusa and Calotis scabiosifolia when they were available. An extreme example occurred in December 1979 when forbs, particularly $B$. diffusa, were not recorded in the pasture but comprised $40 \%$ of the diets in both the modified and control paddocks. Grasses were the major component of the diet when the availability of forbs was low. Diets in the control paddock tended to contain a higher proportion of Dichanthium sericeum and Digitaria plus Panicum spp. than in the modified paddock reflecting the increased availability of these species in the control paddock. Plants of the undesirable Aristida spp. were grazed at all times and their contribution to the diet tended to be highest when that of the forbs was lowest. The variation in diet composition between years was greater than the variation between the paddocks within years.

\section{Diet quality}

Diet nitrogen concentration was high (range 1.7 to $3.3 \%$ ) in March and November 1980, May and November 1981 and November 1983 (Table 6) and was generally associated with high ( $>50 \%$ ) forb content in the diet (Table 5). Diet nitrogen concentration in December 1979 and November 1982 was low (range 0.8 to $1.1 \%$ ) despite a forb content of $40 \%$ in the diet in

Table 3. Ewes joined (\%) in May, ewes pregnant (\%) in August, lambs marked (\%) and lamb liveweight (kg) two weeks after completion of lambing in two Astrebla grassland paddocks between 1979 and 1983

\begin{tabular}{|c|c|c|c|c|}
\hline & Ewes joined & Ewes pregnant & Lambs marked & Lamb liveweight \\
\hline Year & Control Modified & Control Modified & Modified & Control Modified \\
\hline
\end{tabular}

\begin{tabular}{rlccccccc}
\hline 1979 & 94 & 100 & 96 & 92 & 44 & 36 & 7.8 & 7.0 \\
1980 & $80^{*}$ & $70^{*}$ & 98 & 92 & 90 & 70 & 13.3 & 12.9 \\
1981 & 98 & 98 & 88 & 98 & 102 & 128 & 15.2 & 14.8 \\
1982 & 90 & 94 & 92 & 88 & $42+$ & $22+$ & 10.2 & 11.3 \\
1983 & 96 & 96 & 96 & 96 & 72 & 88 & 10.6 & 9.7 \\
\hline
\end{tabular}

* Underestimate because ram harnesses moved

+ Underestimate because of lambs taken by pigs

Table 4. Ewe milk yield (mL/hd/d) two weeks after completion of lambing and lamb growth rate $(\mathrm{g} / \mathrm{hd} / \mathrm{d})$ from the second to sixth week after lambing in two Astrebla grassland paddocks between 1980 and 1983

\begin{tabular}{lrrrr} 
Year & \multicolumn{2}{c}{$\begin{array}{c}\text { Ewe milk yield } \\
\text { Control }\end{array}$} & \multicolumn{2}{c}{ Lamb growth rate } \\
& & & & \\
\hline & & & & \\
1980 & 1,143 & 807 & 209 & 177 \\
1981 & 960 & 1,280 & 143 & 156 \\
1982 & 280 & 380 & 22 & 65 \\
1983 & 1,080 & 1,248 & 203 & 181 \\
& & & & \\
\hline
\end{tabular}

December 1979. Nitrogen: Sulphur ratios in the diet ranged from 6.7:1 in November 1982 to $14.3: 1$ in November 1983. Diet copper levels ranged from 6.4 $\mathrm{mg} / \mathrm{kg}$ in July 1979 to $47.4 \mathrm{mg} / \mathrm{kg}$ in November 1981 while zinc levels ranged from $5 \mathrm{mg} / \mathrm{kg}$ in July 1982 to $47.4 \mathrm{mg} / \mathrm{kg}$ in November 1983. In vitro digestible organic matter ranged from 33.5\% in December 1979 to $72.1 \%$ in November 1983.

High diet quality in November 1980, 1981 and 1983 was associated with high lambing performance (Table 3). In contrast, diet quality was low in December 1979 and November 1982 and lambing performance was poor in these years. 


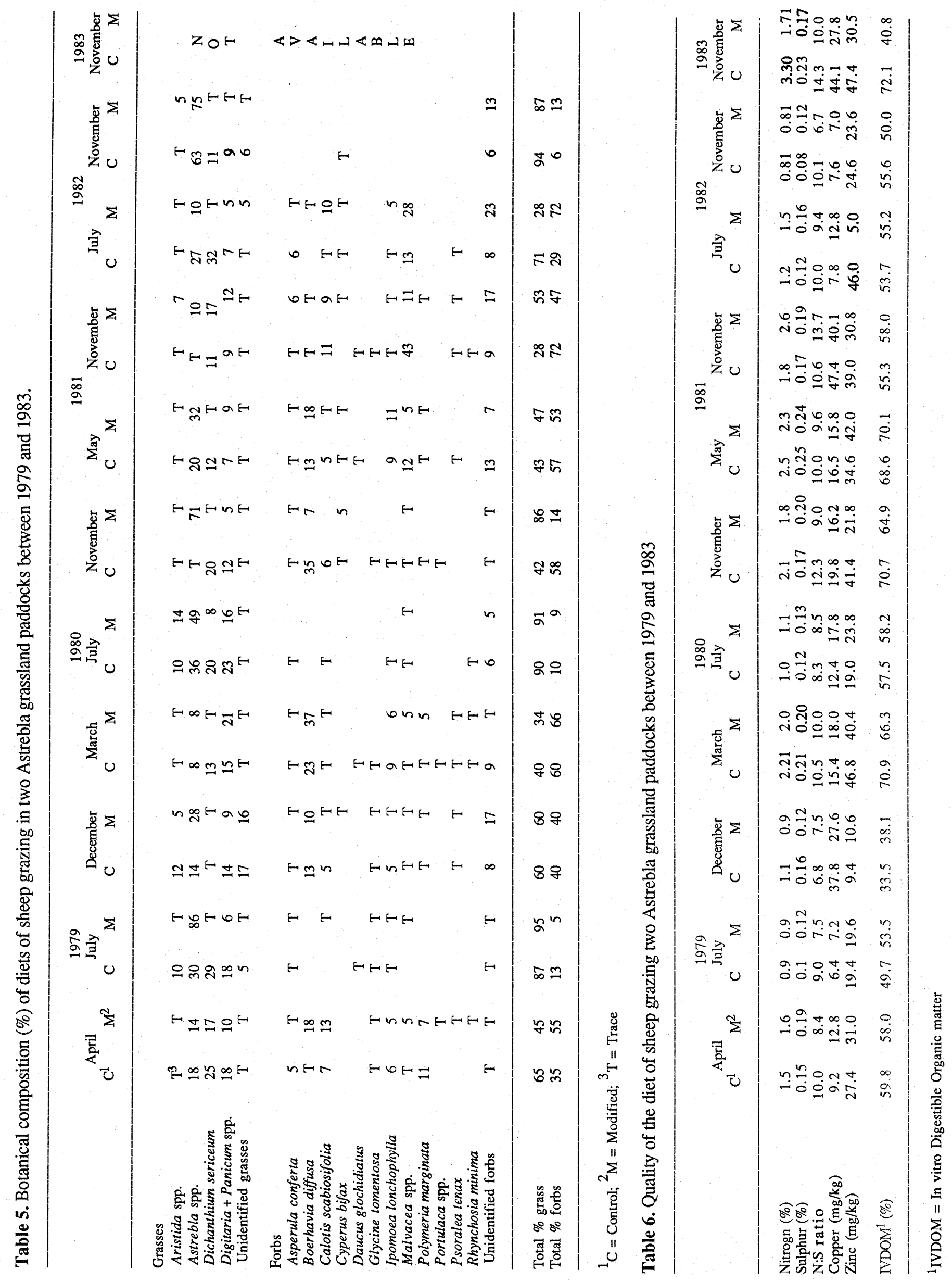




\section{General discussion}

Pasture modification methods employed in this study failed to increase the forb yields and this was probably due to plant competition effects. Forbs species in Astrebla grasslands have a maximum life span of about 2 to 3 years (Orr 1986) so that much of the forb yield comes from new seedlings. The yield of forbs obtained following germinating rains depends on plant competition between the developing forb seedlings and the established perennial grass tussocks, and Cook and Ratcliffe (1984) have indicated that root competition is the major factor influencing seedling establishment under these circumstances. Similarly, reduced basal area of perennial grasses (as an index of root competition) following nine years of heavy grazing (50 and $80 \%$ removal of end of summer forage) was associated with an increase in forb yields at the expense of perennial grass yields (Orr 1986).

Pasture modification reduced the yield of perennial grasses particularly Dichanthium sericeum, Panicum spp. and Digitaria ammophila although the yield of Astrebla spp. was similar in each treatment after 1980. These findings are consistent with other data (Orr 1986) indicating that $D$. sericeum is reduced with increased grazing pressure whereas Astrebla spp. are capable of withstanding moderate (up to about $40 \%$ utilization) grazing pressure without a reduction in yield. In the current study, sheep tended to select $D$. sericeum rather than Astrebla spp., particularly in the control paddock, consistent with the findings of McMeniman et al. (1986a). These authors suggested that the selection for $D$. sericeum may indicate a preference for green leaf rather than for $D$. sericeum per se because $D$. sericeum produced green leaf following rainfall at lower seasonal temperatures than did Astrebla spp. However, no data are available to indicate any advantage to sheep production due to the presence of $D$. sericeum.

Effective rainfall resulted in the growth of a wide range of forb species at any time throughout the year, and a general growth of perennial grasses when temperatures were high $\left(>30^{\circ} \mathrm{C}\right)$. Sheep selectively grazed this new growth, particularly the forbs, which resulted in a high quality diet and the associated sheep productivity was high. In contrast, sheep selected a low quality diet (low in nitrogen and digestibility) when recent rainfall had been insufficient to stimulate new plant growth. Under these conditions, sheep productivity was low. These findings are consistent with other data (McMeniman et al. $1986 \mathrm{a}, \mathrm{b}$ ) indicating an association between seasonal rainfall conditions and the nutritive value of sheep diets.

The large variation in lambing performance from year to year recorded in this study is similar to that in commercial flocks when ewes are joined to lamb in spring (Orr and Holmes 1984). Overall results from this study indicate that the productivity of ewes lambing in spring is determined primarily by diet quality around the time of lambing. This study has not defined the precise point at which reproductive failure occurs when the nutrition of the ewe is poor. However, other studies in south western Queensland (Jordan 1987) indicate that the major period of loss occurs post-lambing. The growth of lambs was influenced by ewe milk yield which, in turn, was also determined by diet quality.

An original aim of this study, to examine the role of forbs in influencing sheep reproduction performance, was not achieved. Nevertheless, the data strongly suggest that reproductive performance is determined mainly by the quality of the diet available around the time of lambing. Rainfall incidence, rather than variable pasture composition, is thus likely to be the dominant factor. Given this, any benefit to reproductive performance due to an increased yield of forbs would be secondary.

The results suggest that the low lamb marking percentages recorded in Astrebla grasslands between 1974 and 1976, each associated with above average rainfall in the preceding summer, probably resulted from poor ewe nutrition due to the low winter and spring rainfall in those years rather than from any effect of the summer rainfall regime on pasture composition.

Data from this study and other data (Orr and Holmes 1984) indicate that spring lambing in this environment achieves highly variable results because rainfall at this time is highly variable. In contrast, lambing in autumn (February to March) may show less variation because diet quality at this time is usually high due to the summer dominant rainfall pattern. However, the advantages of improved lamb survival and growth rate from autumn lambing may be offset by the necessity to join ewes during a time of seasonal anoestrous (Orr and Holmes 1984).

\section{Acknowledgements}

It is a pleasure to acknowledge the co-operation and assistance of $\mathrm{Mr}$ and Mrs Errol Graham and family of "Biddenham", Augathella for the use of livestock and land for this study.

Chemical analyses of samples were conducted by Agricultural Chemistry Branch and the in vitro analyses by Mr Peter Martin of Animal Research Institute, Department of Primary Industries, Brisbane. Dr I.F. Beale supplied botanical identification data for the fistula samples.

This work was supported by a grant from the Wool Research Trust Fund on the recommendation of the Australian Wool Corporation. This support is gratefully acknowledged.

\section{References}

Cook, S.J. and Ratcliffe, D. (1984). A study of the effects of root and shoot competition on the growth of green panic (Panicum maximimum var. trichoglume) seedlings in an existing grassland using root exclusion tubes. J. App. Ecol. 21: 971-87.

Hartley, W. (1979). A checklist of economic plants in Australia. CSIRO, Melbourne. 
Halls, L.D. and Dell, T.R. (1966). Trials of ranked set sampling for forage yields. Forrest Sci. 12: 22-6.

Holmes, W.E. (1983). Blackall downs economic survey 1972-73 to 1980-81. Rural Information Publication No. 2, Dept. of Primary Industries, Charleville.

Jordan, D.J. (1987). Some factors influencing lamb marking percentages in south west Queensland. M.V.Sc. Thesis, University of Queensland.

Lorimer, M.S. (1978). Forage selection studies 1. The botanical composition of forage selected by sheep grazing Astrebla spp. pasture in north west Queensland. Trop. Grass!. 12: 97-108.

McCance, I. (1959). The determination of milk yield in the Merino ewe. Aust. J. Agric. Res. 10: 839-53.

McMeniman, N.P., Beale, I.F. and Murphy, G.M. (1986a). Nutritional evaluation of south west Queensland pastures 1 . The botanical and nutrient content of diets selected by sheep grazing on Mitchell grass and mulga associations. Aust. J. Agric. Res. 37: 289-302.

McMeniman, N.P., Beale, I.F. and Murphy, G.M. (1986b). Nutritional evaluation of south west Queensland pastures 2. The intake and digestion of organic matter and nitrogen by sheep grazing Mitchell grass and Mulga associations. Aust. J. Agric. Res. 37: 303-14.

Orr, D.M. (1980). Effects of sheep grazing Astrebla grasslands in central westem Queensland II. Effects of seasonal rainfall Aust. J. Agric. Res. 31: 807-20
Orr, D.M. (1981). Changes in the quantitative floristics in some Astrebla spp. (Mitchell grass) communities in south westem Queensland in relation to trends in seasonal rainfall. Aust. $J$. Bot. 29: 533-45.

Orr, D.M. and Holmes, W.A. (1984). Mitchell grasslands. In: "Management of Australia's Rangeland". Eds. G.N. Harrington, A.D. Wilson and M.D. Young, CSIRO, Melbourne, pp. 24154.

Orr, D.M. (1986). Factors affecting the vegetation dynamics of Astrebla grasslands. Ph.D. thesis. University of Queensland.

Pratt, M.S. and Hopkins, P.S. (1975). The diagnosis of pregnancy in sheep by abdominal palpation. Aust. Vet. J.51: $378-80$.

Radford, H.H., Watson, R.H. and Wood, G.F. (1960). A crayon and associated hamess for the detection of mating under field conditions. Aust. Vet. J. 36: 57-66.

Sparks, D.R. and Malecheck, J.C. (1968). Estimating percentage dry weight in diets using a microscopic technique. J. Range. Mgmt. 21: 264-5.

Tilley, J.M.A. and Terry, R.A. (1963). A two-stage technique for the in vitro digestion of forage crops. J. Br. Grassl. Soc. 18: 104-11.

Turner, E.J. (1978). Land systems. In: "Western Arid Region Land Use Siudy - Part 4". Qld. Dept. Prim. Ind., Land Use Tech. Bull. No. 23 .

Manuscript received 18 November 1987 , accepted 15 April 1988 